\title{
Separate Spheres: Analytical Persistence in United States Women's History
}

Kim Warren*

University of Kansas

\section{Abstract}

Since the 1960s United States women's history has seen a dramatic rise in productivity, reclamation of the past, innovation of new theories and strategies, and analysis of the roles of women in society. Despite this growth, or perhaps because of it, a persistent debate about "separate spheres" has provided a common thread within scholarship of the past four decades. Original separate spheres scholarship demonstrated how the sexual division of labor intensified through industrialization in the mid-nineteenth century. Subsequent scholarship critiqued separate spheres metaphors, calling attention to the ways in which women of color have rarely had the privilege of occupying a strictly domestic realm. Such arguments only encouraged more analysis and application of separate spheres metaphors until questions about women's and men's roles in society, private and public realms, domestic and political influence pervaded most scholarship about women regardless of race, class, and region.

Once a field that struggled to simply place women into the historical narrative of the United States, women's history is now thriving and expanding to include not only gender as a category of analysis, but also race, class, sexuality, and often religion, age, and ability. No longer is women's history simply compensatory or recuperative. Rather, there has been rapid growth in the publishing of scholarship, the certification of women's history and gender history graduate programs, and the establishment of scholarly communities. For more than four decades, "separate spheres" ideology has been defined, challenged, and revised to the point that scholars cannot write women's or gender history without adding their own ideas about the boundaries that have connected or divided women's and men's experiences.

Original separate spheres scholarship of the 1960s and 1970s demonstrated how the sexual division of labor intensified through industrialization in the mid-nineteenth century. This analysis established an ideology that could both bring women to the center of American history and legitimize the study of "private" as well as "public" realms. Separate spheres provided a framework for thinking about women's and men's economic, labor, social, and cultural experiences as distinctly gendered, sometimes separate, and always in relationships of power. Separate spheres of influence were often coded as domestic for women and political for men. 
In the 1980s, scholars who researched histories of women of color critiqued separate spheres metaphors calling for attention to the ways in which African American women, in particular, have rarely had the privilege of occupying a strictly domestic realm. Others suggested that separate spheres could only apply to white or middle-class or northeastern women, the subjects of early studies. Such arguments did not diminish the use of separate spheres, but rather increased the utilization of the ideology. Although examined from various vantage points, separate spheres continues to provide an analytical tool for understanding the history of women's and men's relationships of power with each other, with members of their own sex, and with the larger society.

\section{Separate Spheres Ideology}

The original scholarship about separate spheres argued that in a private and domestic realm, women developed authority and female networks that provided both social and economic support. This sphere was distinct from men's spheres, which were largely public and often political. In the late 1970s, Barbara Welter and Carroll Smith-Rosenberg demonstrated the particular nature of women's spheres as domestic, pious, pure, and submissive, yet also affectionate and loving. ${ }^{1}$ Nancy Cott further showed that women had used traditionally female qualities to influence the world around them. In churches, health and moral reform, benevolent associations, abolition and women's rights organizations, and their homes, women found a "doctrine of woman's sphere" that was not only open to them but also reserved for them. "For women who previously held no particular avenue of power of their own - no unique defense of their integrity and dignity this represented an advance," Cott argued. ${ }^{2}$ The woman's sphere also contained "the preconditions for organized feminism, by allotting a 'separate' sphere for women and engendering sisterhood within that sphere." 3

Although some subsequent scholars interpreted the notion of separate as completely divergent, and therefore accused it of being an inaccurate description of gendered experiences, the original scholarship never intended to mark gender disconnection. Over twenty years after Cott published Bonds of Womanhood, she wrote a clarification of what she considers a misunderstanding of the use of separate spheres ideology:

Women's historians of the 1970s, including myself, who wrote about the construction of "woman's sphere," were using nineteenth-century language, not inventing rubrics; we were trying to investigate the origins, trace the impact, and understand the longevity of a set of gender expectations about men's and women's natures and social roles. ${ }^{4}$

That is, the ideology was meant to understand a set of rules, negotiations, and intersections that placed women and men into distinct positions in society rather than on divergent paths. Linda Kerber had made this point in 1988, when she explained the metaphor of a sphere as "the figure of speech, 
the trope, on which historians came to rely when they described women's part in American culture." ${ }^{5}$ Kerber traced the use of a sphere back to Alexis de Tocqueville and his perennial attempt to describe the nuances of life in the United States. Kerber explained that many have found the concept of a sphere useful to explain gender dynamics, including psychologist Erik Erikson, who in 1964, concluded that girls and boys played with blocks in different ways depending on their orientation for "Inner and Outer Space." Historians, too, have found the metaphor of separate spheres to be an extremely helpful ideology in the 1960s, to locate women's historical experiences, and in the 1970s, "to refine the definition and identify complexities" in women's culture. In the 1980s, Kerber argued, historians had solidified the ideology so that diaries, letters, organization records, and other sources that helped to capture women's lives could be analyzed and appreciated in scholarly ways. ${ }^{7}$ The third stage in the development of the metaphor of separate spheres has taken into account how men affected women and how women affected men. She stated that "in short, that sphere was socially constructed both for and $b y$ women."

Despite such clarification by architects of and commentators on separate spheres, debate about the usefulness of the ideology has continued. In the 1980s, historians called for more inclusion and a way to use separate spheres that seemed less white, less middle-class, and less northeastern. Most pointedly, Jacqueline Jones and Deborah Gray White illustrated the ways in which black women had never enjoyed the privilege of a life without labor outside of the home. ${ }^{9}$ Therefore, more scholars expanded the notion of separate spheres to include not just domestic labor but activity outside of the home, especially where women of color were concerned. Black women's work - paid and unpaid, under supervision of whites and within their own communities, and in comparison to white women's work - garnered much attention. Scholarship that examined work trends in World War II showed particular hiring and firing differences in the experiences of white and black women. ${ }^{10}$ Additionally, African American women's activism as it intersected with the public spheres of politics became important to scholars. ${ }^{11}$

Still, there were other scholars who wanted to disengage with separate spheres ideology all together. Helena Znaniecka Lopata stated that the two-spheres imagery "was, and still is, an artificial polarity that ignores the continuum of social relations in real life and which has become increasingly dysfunctional to modern life." 12 In the late 1990s, the editors of $A$ Shared Experience: Men, Women, and the History of Gender allowed their contributors to critique separate spheres as if the metaphor never allowed for the interplay of men's and women's worlds. ${ }^{13}$ Manuela Thurner claimed that the separate spheres paradigm had achieved a kind of theoretical prominence, but also argued that historians of racial and ethnic minorities, lesbians, and others found the ideology to restrictive. ${ }^{14}$ Nancy Hewitt argued that race and class lines prevented an inclusive female community from developing in the nineteenth century. ${ }^{15}$ Christopher Olsen interpreted women's involvement 
in electoral politics, reading of the party press, and public speaking as evidence that separate spheres was a "fiction." 16

Although critiques to expand separate spheres ideology have continued, the majority of scholars do not agree with critics who would throw out the ideology all together. Instead the demand for inclusion of race as a category of analysis, along with gender, has helped to propel the conversation even further to include multiple layers of examination when trying to analyze women's spheres of influence. In addition to merging racial categories with gender, scholarship in the 1990s and first decade of the twenty-first century has complicated what Shirley Hune has called "women's everyday experiences" to include class, sexuality, religion, national origin, citizenship status, and other categories at the center of analysis. ${ }^{17}$ Although approaches and methods vary, what remains is the persistent effort to understand gender hierarchy through the ideology of separate spheres. Another common thread is a desire to understand the dynamic between private and public spheres for women, as well as women's entry into public sphere politics and reform efforts.

\section{Claiming the Public Sphere}

These concerns have been particularly useful for historians of women's labor, who have illustrated women's movement between private and public spheres. Vicki Ruiz demonstrated that Chicana women in cannery work were tied to family economies and consumer economies. She argued,

If part of a family economy, women labored to put food on the table, but if more financially secure and consumer-oriented, they worked in order to purchase the "extras" - stylish clothes, a radio, a phonograph. ${ }^{18}$

Patricia Zavella's work also demonstrated the inseparable link between work and family for Chicana women. She showed that Chicana women have worked for wages both in other women's homes and outside of the domestic sphere, and that work has affected "egalitarian" qualities of family life and their roles as wives and mothers. ${ }^{19}$ To make her point, Zavella highlighted Elizabeth Pleck's work to suggest that where women's work and family are concerned, there are "two worlds in one." ${ }^{20}$

The metaphor of spheres has even helped scholars recast the role of motherhood, once a strictly domestic category. In a contemporary study of women's work, Louise Lamphere and Felipe Gonzales showed that women, specifically mothers, are at the center of demographic, cultural, and economic changes that define American families. ${ }^{21}$ They defined women's work in three types: secondary providers, coproviders, and mainstay providers earning less than their husbands, the same as their husbands, and holding the steady job in the family, respectively. ${ }^{22}$ Their history acknowledged the relationship between private and public realms by examining not only the experiences of women in the workforce but also how women have helped 
transform their work environments, including management. Highlighting the intersection of private and public labor, this scholarship has shown how women's social networks support their families but also help them maintain their work.

In addition to exploring the intersection of spheres in labor, other scholars have used the metaphor of spheres to show how women have created their own networks in the public, rather than private realm. Estelle Freedman demonstrated that when women created women-focused institutions, they could expand to the public realm and create a unique female culture, where the goal of women's equality remained central. ${ }^{23}$ Regarding networks that prompted feminist politics, Freedman argued,"The creation of a separate, public female sphere helped mobilize women and gained political leverage in the larger society." It would be "female institution building" that would make women's culture integral to feminist politics. ${ }^{24}$

Examining women's institution building allowed historians to bring the experiences of women of color and working-class women into sharper focus. The 1870 s to 1920 s saw a growth in club women's movements. Such separate institutions for women were important for both white and black women as they turned their attention to temperance, suffrage, education, and other issues through the National Association of Colored Women, founded in 1896, and the Women's Christian Temperance Union (WCTU), founded in 1874. ${ }^{25}$ Annelise Orleck wrote about how working-class women organized themselves in the Women's Trade Union League. ${ }^{26}$ Ethnicity sometimes linked women around specific issues that affected them as both women and minorities. Margaret Rose demonstrated how Chicana organizers made efforts to build alliances with white, middleclass women in order to boycott grapes and subsequently support farm workers in the late 1960s and early 1970s. ${ }^{27}$ Glenda Gilmore discussed the ways in which African American women, feeling excluded from white women's organizational efforts in the WCTU, founded their own auxiliaries to focus on both gender and race issues. ${ }^{28}$ Sixteen years after her first separatism article, Estelle Freedman reconsidered women's institution building by tracing the legacy of separatism through the early decades of the twentieth century through the 1960s. Women's networking supported their entry into governmental departments during the New Deal and unionization, especially in jobs where sexual segregation of labor defined the workplace, such as in restaurants and canneries. Same-sex, romantic relationships among women that proliferated in settlement houses, armed forces, bars of the 1950s, and other lesbian subcultures, provided a means of support for activists. Women's activism in the peace movement and antilynching movement in the South also demonstrated how the development and separate institutions had benefited them. ${ }^{29}$

The 1990s and 2000s saw a growth in scholarship that demonstrated women's understanding of their traditional roles and their ability to use their distinct gender attributes to penetrate the public spheres. Scholars showed 
that as reformers, women drew on different resources and strategies than men had used to change labor legislation and even to develop a national presence in journalism. Women moved the settlement movement into political avenues and they used women's networks to dictate neighborhood codes and rules to fit their own version of Progressive reform. ${ }^{30}$ Elite, white women exercised their political influence through their husbands and thereby entered into party politics. ${ }^{31}$ And, there were others who continued to use the mask of traditionally female realms of church and educational work to disguise their concerns for larger political and social relations without raising the concerns of clergy and other authorities. Many of these women, historians have argued, were well aware of the ideals of proper womanhood for their time period, but deliberately transgressed those boundaries. ${ }^{32}$ Barbara Cutter's examination of murderesses, sexual transgressors, public speakers, and Civil War workers demonstrated the ways in which women saw the tension between the social prescriptions of their roles (private) and their actual lives (public). ${ }^{33}$ African American, sometimes excluded from white women's organizations, entered public avenues of philanthropic, political, and organized reform work as well. Frustrated by sexism that existed in civil rights organizations, they also formed their own alliances to combat the multiple prejudices that they faced. ${ }^{34}$

Although the ideology of spheres proved to be useful in examining women's work and activism, there was still some debate about its efficacy where scholarship about women of color was concerned. A collection that has most actively answered questions about the ideology in writing women's history has been Unequal Sisters: A Multicultural Reader in U.S. Women's History, which debuted in 1990 and has been reissued two more times. Instead of discounting separate spheres, scholars in Unequal Sisters have expanded the metaphor beyond domestic realms and have built a theoretical framework that moves beyond relegating white women as raceless and women of color as invisible. In addition to essays that place women at the center of histories of World War II, politics, unions, jazz, education, and more, the Unequal Sisters editions have provided commentary of the state of women's history and selected bibliographies organized by ethnic groups, including African American, Asian American, Latina, and Native American women. In the third edition,Vicki Ruiz and Ellen Carol DuBois reminded their readers that diversity in women's experiences "can no longer be satisfied by token excursions into the histories of minority women, lesbians, and the working class." Instead, women's history has to be "remapped." ${ }^{35}$ Ruiz and DuBois argued that scholarship in Unequal Sisters offered a new theoretical layer where power relations between women stand at the very center defining women's history. "Slave owner and slave, mistress and maid, reformer and immigrant, and social worker and client are some of the many relationships of inequality that run through women's history," the editors noted. ${ }^{36}$

In addition to shifting focus to multiple racial categories within women's history, the essays in Unequal Sisters moved the regional focus away from 
women in the Northeast to women in the American Southeast and West. They acknowledged that a regional focus is inherently problematic: "Even the term 'the West' reflects only one of several historical perspectives; the Anglo 'West' is also the Mexican 'North', the Native American 'homeland,' and the Asian 'East.', ${ }_{37}$ Earlier editions of Unequal Sisters certainly contributed to the popularity of "race, class, and gender" as a contemporary shorthand for lenses through which to examine American history. However, the third edition has gone further by expanding that triad into more categories of analysis, including masculinity, transnationalism, racialized sexuality, memory, and cultural representations. ${ }^{38} \mathrm{With}$ these multiple lenses, women's sphere has gotten substantially larger.

Scholars of Asian American women's history have continued the work of merging multiple categories of analysis. Shirley Hune argued that without a focus on women's specific experiences as gendered beings, scholars would not have been able to bring the field to a point where Asian/Pacific Islander American women are viewed as active participants in history. In this framework, women are "agents of social change, negotiating complex structures of power" and their lives are "dynamic, complicated, and multifaceted." Hune added,

Their contributions to family, community, and society; their social and cultural formations and activities; and the simultaneity of their subordination and resistance to multiple forms of oppression, among other aspects, are acknowledged. ${ }^{39}$

Regarding separate spheres, Hune was even more pointed: "The lived realities of Asian/Pacific Islander American women are everywhere - private and public spheres; local, regional, national, and global arenas; and in between." ${ }^{40}$ Within the anthology, the construction of spheres and women's intersection of them was explored through family, identity, work, community, gender roles, cultural production, women's struggle for dignity and their resistance against subordination. The collection analyzed women's sexual, social, and economic lives in the absence of men, gender inequity in their households, and inequality in their ethnic communities. Whether the subjects are military brides or workers in global and domestic economies, the scholarship showed ways in which women's experiences cross spheres of gender, as well as race and economic boundaries.

Recent scholarship has continued to examine gender in relationship with race and other categories, and its acknowledgment of the usefulness of separate spheres as an analytical tool also persists. In her biography of Margaret Chung, the first Asian American woman doctor in the United States, Judy Wu argued that the missionary movement that encouraged Chung's career path "both relied upon and challenged Victorian practices of gender separatism, immigration restriction, and segregation.. ${ }^{41} \mathrm{Wu}$ defined separate spheres as categories, "which assigned men and women different responsibilities on the basis of 'inherent' gender differences." 42 Margaret Chung's decision to become a doctor was only one of many ways that she 
crossed the boundaries that separated men's and women's spheres of influence. A racial and gender minority throughout her medical training, Chung often dressed in masculine clothing. She hosted weekly Sunday parties for seventy-five to a hundred people in her home, cooking for them and tending to her guests, but these domestic gatherings of her adopted family - a family that grew to approximately fifteen hundred members represented more than an extension of Chung's maternal role. She indeed became known as Mom Chung, a traditionally maternal figure to a group of mostly white men known as "Fair-Haired Bastards." However, it was through this adopted family that Chung drew resources during the 1930s and 1940s to recruit pilots for an American volunteer force that supported China during the Sino-Japanese War. It was also through her constructed family that she made contacts to help establish a formal role for women to enlist in the military during World War II, the creation of the WAVES, the Women's Naval Reserve. ${ }^{43}$ Wu argued that it was Chung's ability to craft multiple personas and her "dual ability to transverse social barriers yet personify the immutability of social difference" that allowed her to operate in multiple racial and gender categories. Regarding Chung's ability to shift between spheres, Wu wrote:

She transformed herself from a medical professional who adopted masculine clothing to a glamorous and feminine mother figure. She assimilated into mainstream and even elite American society but remained a symbol of China, a country that she never visited. She became a respectable public figure, yet she lived an unconventional private life that included developing romantic relationships with other women. ${ }^{44}$

It was precisely Chung's knowledge of separate spheres that enabled her to define roles as a doctor, mother, and political influence that both reinforced and challenged prevailing gender realms.

\section{Future State of Spheres}

To mark boundaries and to define them is confusing work. However, attempts to define gender spheres continue to persist, and because of the ideology of separate spheres, the fields of women's and gender history have opened further. As Linda Kerber has put it: "Quite as much energy, male and female, has gone to maintain boundaries as to break them down." ${ }^{45}$ Nancy Cott and Drew Gilpin Faust recently stated that there has always been "social meanings attributed to the binary division between men and women" and that defining and acting out of gender attributes and properties will appear "in every arena in which women and men life and interpret their lives." 46

Historians have certainly nullified the question of whether or not women should be included as subjects in the writing of history. Essentialist questions about the biological nature of women have been replaced by arguments that demonstrate the social construction of gender roles in various times and 
places in history. But the investigation of how women have lived, worked, organized, and created in distinct, separate, and integrated spheres still persists. It has endured because the ideology of spheres has provided an essential tool in finding the limits of women's prescribed roles. But is has also persevered because it has helped scholars recognize when and where women have crossed such boundaries. The ideology will continue to be a useful tool because with an understanding of intended gender boundaries scholars will be able to continue to identify the expansion of such limits.

Despite the rapid expansion of the field of gender history, at the center of scholarship are questions that have been asked for several decades: How have women and men constructed their identities in distinct and sometimes separate ways? How have those identities intersected in relationships of power with each other? Answers to those questions have been diverse in content and approach, but scholars have also shown continuity in their quest for answers by using separate spheres as an ideological framework. More recent scholarship has demonstrated that gender cannot stand alone as a lens for analysis. Rather, with the increased attention paid to positions of class, race, religion, and other categories of experiences, scholars of women's history must go on with merging gender and other identity groupings. As a result, scholars will continue to provide a more precise history of women's experiences that also reflects a complicated spectrum of women's limits and liberation.

\section{Short Biography}

Kim Warren is Assistant Professor of United States and Women's History at the University of Kansas. She earned a Ph.D. in History from Stanford University in 2004; an M.A. from Stanford University in 1999; and a B.A. in American Studies from Yale University in 1994. Warren's research and teaching interests include the history of gender and race formation, African American and Native American education, and late-nineteenth-century reform. She is currently completing a manuscript on education, race, and citizenship in the American West.

\footnotetext{
Notes

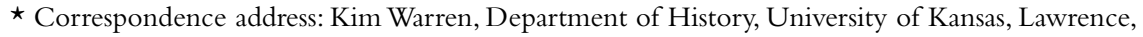
KS 66045, USA. Email: kwarren@ku.edu.

1 B. Welter, "The Cult of True Womanhood, 1820-1860," American Quarterly, 18 (Summer 1966): 151-74; C. Smith-Rosenberg, "The Female World of Love and Ritual: Relations between Women in Nineteenth-Century America," Signs, 1 (Autumn 1975): 1-29.

${ }^{2}$ N. Cott, The Bonds of Womanhood: "Woman's Sphere” in New England, 1780-1835 (New Haven, CT: Yale University Press, 1977), 200.

${ }^{3}$ Ibid., 201. For studies of women in the colonial and early nineteenth-century periods, see K. Brown, Good Wives, Nasty Wenches, and Anxious Patriarchs: Gender, Race, and Power in Colonial Virginia (Chapel Hill: University of North Carolina Press, 1996); C. Hughes Dayton, Women before the Bar: Gender, Law, and Society in Connecticut, 1639-1789 (Chapel Hill: University of North
} 
Carolina Press, 1995); M. Norton, Founding Mothers and Fathers: Gendered Power and the Forming of American Society (New York: Alfred A. Knopf, 1996).

${ }^{4}$ N. Cott, "Review of $A$ Shared Experience: Men, Women, and the History of Gender," ed. L. McCall and D. Yacovone, American Historical Review, 105/1 (February 2000): 171.

${ }^{5}$ L. Kerber, "Separate Spheres, Female Worlds, Woman's Place: The Rhetoric of Women's History," The Journal of American History, 75/1 (June 1988): 10. For other overviews of the field, see N. Hewitt, “Taking the True Woman Hostage," Journal of Women's History, 14/1 (2002): 156-62; N. Cott, G. Lerner, K. Kish Sklar, E. DuBois, and N. Hewitt, "Considering the State of U.S. Women's History," Journal of Women's History, 15/1 (2003): 145-63.

${ }^{6}$ Kerber, "Separate Spheres," 10-11.

${ }^{7}$ Ibid., 17.

${ }^{8}$ Ibid., 18.

9 J. Jones, Labor of Love, Labor of Sorrow: Black Women, Work, and the Family from Slavery to the Present (New York: Basic Books, 1985); D. Gray White, Ar'n't I a Woman?: Female Slaves in the Plantation South (New York: Norton, 1985). Other scholarship includes D. Clark Hine, W. King, and L. Reed (eds.), "We Specialize in the Wholly Impossible": A Reader in Black Women's History (New York: Carlson Publishing, 1995); T. Hunter, To 'Joy My Freedom: Southern Black Women's Lives and Labors after the Civil War (Cambridge: Cambridge University Press, 1997).

${ }^{10}$ K. Anderson, "Last Hired, First Fired: Black Women Workers during World War II," Journal of American History, 69/1 (June 1982): 82-97; Anderson, Wartime Women: Sex Roles, Family Relations, and the Status of Racial Ethnic Women in Modern America (Westport, CT: Greenwood Press, 1981); D. Clark Hine, Hine Site: Black Women and the Re-Construction of American History (New York: Carlson Publishing, 1994); E. Clark-Lewis, Living In, Living Out: African-American Domestics in Washington, D.C., 1910-1940 (Washington, D.C.: 1994); M. Honey, Creating Rosie the Riveter: Class, Gender, and Propaganda during World War II (Amherst: University of Massachusetts Press, 1984); Honey (ed.), Bitter Fruit: African American Women in World War II (Columbia: University of Missouri Press, 1999); T. Hunter,"Domination and Resistance: The Politics of Wage Household Labor in New South Atlanta," Labor History, 34 (Spring-Summer 1993): 205 - 20; G. Lemke-Santangelo, Abiding Courage: African American Migrant Women and the East Bay Community (Chapel Hill: University of North Carolina Press, 1996); S. Moore, “'Not in Somebody's Kitchen': African American Women Workers in Richmond, California, and the Impact of World War II," in E. Jameson and S. Armitage (eds.), Writing the Range: Race, Class, and Culture in the Women's West (Norman: University of Oklahoma Press, 1997), 513-16.

${ }^{11}$ E. Boris, "The Power of Motherhood: Black and White Activist Women Redefine the Political," in S. Koven and S. Michel (eds.), Mothers of a New World: Maternalist Politics and the Origins of Welfare States (New York: Routledge, 1993), 213-45; E. Barkley Brown, "Negotiating and Transforming the Public Sphere: African American Political Life in the Transition from Slavery to Freedom," Public Culture, 7 (Fall 1994): 108-24; E. Barkley Brown, "To Catch a Vision of Freedom: Reconstructing Southern Black Women's Political History, 1865-1880," in V. Ruiz and Ellen C. DuBois (eds.), Unequal Sisters: A Multicultural Reader in U.S. Women's History, ${ }^{\text {rd }}$ edn. (New York: Routledge, 2000), 124-46. For more on African American women's activism, see S. Yee, Black Women Abolitionists: A Study in Activism, 1828-1860 (Knoxville: University of Tennessee Press, 1992).

${ }^{12}$ H. Znaniecka Lopata, "The Interweave of Public and Private: Women's Challenge to American Society," Journal of Marriage and the Family, 55/1 (February 1993): 176.

${ }^{13}$ L. McCall and D. Yacovone (eds.), A Shared Experience: Men, Women, and the History of Gender (New York: New York University Press, 1998).

${ }^{14}$ M. Thurner, "Subject to Change: Issues and Paradigms of U.S. Feminist History," Journal of Women's History, 9/2 (Summer 1997): 122-46.

${ }^{15}$ N. Hewitt, "Beyond the Search for Sisterhood: American Women's History in the 1990s," in V. Ruiz and E. DuBois (eds.), Unequal Sisters: A Multicultural Reader in U.S. Women's History, $3^{\text {rd }}$ edn. (New York: Routledge, 2000), 1-19.

${ }^{16}$ C. Olsen, "Respecting 'the Wise Allotment of Our Sphere': White Women and Politics in Mississippi, 1840-1860," Journal of Women's History, 11/3 (Autumn 1999): 104-25.

${ }^{17}$ S. Hune, "Introduction: Through 'Our' Eyes: Asian/Pacific Islander American Women's History," in S. Hune and G. Nomura (eds.), Asian/Pacific Islander American Women: A Historical Anthology (New York: New York University Press, 2003), 6. 
18 V. Ruiz, Cannery Women, Cannery Lives: Mexican Women, Unionization, and the California Food Processing Industry, 1930-1950 (Albuquerque: University of New Mexico Press, 1987), xvi. Studies that include discussions of white women's contributions to their household economy include J. Boydston, Home and Work: Housework, Wages, and the Ideology of Labor in the Early Republic (New York: Oxford University Press, 1990); L. Thatcher Ulrich, A Midwife's Tale: The Life of Martha Ballard, Based on Her Diary, 1785-1812 (New York: Vintage Books, 1991).

${ }^{19}$ P. Zavella, Women's Work and Chicano Families: Cannery Workers of the Santa Clara Valley (Ithaca: Cornell University Press, 1987), xvii.

${ }^{20}$ E. Pleck quoted in ibid., 2. See E. Pleck, "Two Worlds in One," Journal of Social History, 10/2 (1976): 178-95.

${ }^{21}$ L. Lamphere, P. Zavella, F. Gonzales with P. Evans, Sunbelt Working Mothers: Reconciling Family and Factory (Ithaca: Cornell University Press, 1993), x.

22 Ibid., xi.

${ }^{23}$ E. Freedman, "Separatism as Strategy: Female Institution Building and American Feminism, 1870-1930," in Feminism, Sexuality, and Politics: Essays by Estelle B. Freedman (Chapel Hill: University of North Carolina Press, 2006), 21-36. (Also see original publication, E. Freedman, "Separatism as Strategy: Female Institution Building and American Feminism, 1870-1930," Feminist Studies, 5/3 (Fall 1979): 512-29.)

${ }^{24}$ Freedman, "Separatism as Strategy," 23.

${ }^{25}$ For more on black women's organizations, see L. Dickson, "Lifting as We Climb: African American Women's Clubs of Denver, 1890-1925," in E. Jameson and S. Armitage (eds.), Writing the Range: Race, Class, and Culture in the Women's West (Norman: University of Oklahoma Press, 1997), 372-92; P. Giddings, Where and When I Enter: The Impact of Black Women on Race and Sex in America (New York: Bantam Books, 1984); D. Gray White, Too Heavy a Load: Black Women in Defense of Themselves, 1894-1994 (New York: W. W. Norton, 1999).

${ }^{26}$ A. Orleck, "Rose Schneiderman," in G. J. Barker-Benfield and C. Clinton (eds.), Portraits of American Women: From Settlement to the Present (New York: St. Martin's Press, 1991), 401-21.

${ }^{27}$ M. Rose, “'Woman Power Will Stop Those Grapes': Chicana Organizers and Middle-Class Female Supporters in the Farm Workers' Grape Boycott in Philadelphia, 1969-1970," Journal of Women's History, 7/4 (Winter 1995): 6-36. Other scholarship on women and unions includes D. Cobble, Dishing It Out: Waitresses and Their Unions in the Twentieth Century (Urbana: University of Illinois Press, 1991).

${ }^{28}$ G. Gilmore, Gender and Jim Crow: Women and the Politics of White Supremacy in North Carolina, 1896-1920 (Chapel Hill: University of North Carolina Press, 1996).

${ }^{29}$ E. Freedman, "Separatism Revisited: Women's Institutions, Social Reform, and the Career of Miriam Van Waters," in L. Kerber, A. Kessler-Harris, and K. Kish Sklar (eds.), U.S. History as Women's History: New Feminist Essays (Chapel Hill: University of North Carolina Press, 1995), 170-88. For a discussion of women's activism between 1920 and the 1960s, a period of time previously thought of as the doldrums for feminist activity, see N. Cott, The Grounding of Modern Feminism (New Haven, CT: Yale University Press, 1987); L. Rupp and V. Taylor, Survival in the Doldrums: The American Women's Rights Movement, 1945 to the 1960s (New York: Oxford University Press, 1987).

30 B. Dorsey, Reforming Men and Women: Gender in the Antebellum City (Ithaca, NY: Cornell University Press, 2002); K. Kish Sklar, "Two Political Cultures in the Progressive Era: The National Consumers' League and the American Association for Labor Legislation," in L. Kerber, A. Kessler-Harris, and K. Kish Sklar (eds.), U.S. History as Women's History: New Feminist Essays (Chapel Hill: University of North Carolina Press, 1995), 36-62; E. Rauchway, "A Gentlemen's Club in a Woman's Sphere: How Dorothy Whitney Straight Created the New Republic," Journal of Women's History, 11/2 (1999): 60-85; E. Lasch-Quinn, Black Neighbors: Race and the Limits of Reform in the American Settlement Movement, 1890-1945 (Chapel Hill: University of North Carolina Press, 1993); K. Blee, Women of the Klan: Racism and Gender in the 1920s (Berkeley: University of California Press, 1991).

31 C. Allgor, Parlor Politics: In Which the Ladies of Washington Help Build a City and a Government (Charlottesville: University Press of Virginia, 2000); J. Freeman, A Room at a Time: How Women Entered Party Politics (Lanham, MD: Rowman and Littlefield, 2000); M. Gustafson, Women and the Republican Party, 1854-1924 (Urbana: University of Illinois Press, 2001); N. Hewitt, Southern Discomfort: Women's Activism in Tampa, Florida, 1880s-1920s (Urbana: University of Illinois Press, 
2001); M. Ryan, Women in Public: From Banners to Ballots, 1825-1880 (Baltimore, MD: Johns Hopkins University Press, 1990); E. Varon, “Tippecanoe and the Ladies, Too: White Women and Party Politics in Antebellum Virginia," Journal of American History, 82 (September 1995): 494521. For a discussion of international influences on American women's activism, see B. Anderson, Joyous Greetings: The First International Women's Movement, 1830-1860 (New York: Oxford University Press, 2000). Joan Landes offers a reflection on public/private dichotomies using scholarship on both American and international history in J. Landes, "Further Thoughts on the Public/Private Distinction," Journal of Women's History, 15/2 (2003): 28-39. An earlier work on women and political sensibilities is P. Baker, "The Domestication of Politics: Women and American Political Society, 1780-1920,” American Historical Review, 89 (June 1984): 620-47.

32 E. Boris, Home to Work: Motherhood and the Politics of Industrial Homework in the United States (Cambridge: Cambridge University Press, 1994); A. Boylan, The Origins of Women's Activism: New York and Boston, 1797-1840 (Chapel Hill: University of North Carolina Press, 2002); L. Ginzberg, Women and the Work of Benevolence: Morality, Politics, and Class in the Nineteenth-Century United States (New Haven, CT: Yale University Press, 1990); E. Brooks Higginbotham, Righteous Discontent: The Women's Movement in the Black Baptist Church, 1880-1920 (Cambridge, MA: Harvard University Press, 1993); P. Pascoe, Relations of Rescue: The Search for Female Moral Authority in the American West (New York: Oxford University Press, 1990).

33 B. Cutter, Domestic Devils, Battlefield Angels: The Radicalism of American Womanhood, 1830-1870 (DeKalb: Northern Illinois University Press, 2003).

34 D. Salem, To Better Our World: Black Women in Organized Reform, 1890-1920 (New York: Carlson Publishing 1990); A. Firor Scott, "Most Invisible of All: Black Women's Voluntary Associations," Journal of Southern History, 56 (February 1990): 3-22; S. Shaw, "Black Club Women and the Creation of the National Association of Colored Women," Journal of Women's History, 3 (Fall 1991): 10-25. Jacqueline Jones gives an overview of the roles of women in civil rights and race reform movements in J. Jones, "Race and Gender in Modern America," Reviews in American History, 26/1 (1998): 220-38. Also see V. Crawford, J. Rouse, and B. Woods (eds.), Women in the Civil Rights Movement: Trailblazers and Torchbearers, 1941-1945 (Bloomington: Indiana University Press, 1993); B. Robnett, How Long? How Long? African American Women in the Struggle for Civil Rights (New York: Oxford University Press, 1996).

${ }^{35}$ V. Ruiz and E. DuBois (eds.), Unequal Sisters: A Multicultural Reader in U.S. Women's History, $3^{\text {rd }}$ edn. (New York: Routledge, 2000), xi.

36 Ibid., xii.

37 Ibid. Also see S. Deutsch, No Separate Refuge: Culture, Class, and Gender on the Anglo-Hispanic Frontier in the American Southwest, 1880-1940 (New York: Oxford University Press, 1987). Elizabeth Jameson wrote that the term "western" was problematic: "What Anglos called the 'West' was, after all, simply home for American Indians, the 'East' for Asians, the 'South' for Canadians, and 'El Norte' or northwestern Mexico for Mexicans and Spanish-Mexicans.' See E. Jameson, "Toward a Multicultural History of Women in the Western United States," Signs, 13/4 (Summer 1988): 761. Also see E. Jameson and S. Armitage (eds.), Writing the Range: Race, Class, and Culture in the Women's West (Norman: University of Oklahoma Press, 1997).

${ }^{38}$ Ruiz and DuBois, xiv. For more on masculinity, see G. Bederman, Manliness and Civilization: A Cultural History of Gender and Race in the United States, 1880-1917 (Chicago: University of Chicago Press, 1995); K. Dalton, Theodore Roosevelt: A Strenuous Life (New York: Alfred A. Knopf, 2002); S. Watts, Rough Rider in the White House: Theodore Roosevelt and the Politics of Desire (Chicago: University of Chicago Press, 2003); S. Wilson, "Melville and the Architecture of Antebellum Masculinity," American Literature, 76/1 (2004): 59-87.

${ }^{39}$ Hune, Creating Roise the Riveter, 6. For more on Asian American women's history, see E. Nakano Glenn, Issei, Nisei, War Bride: Three Generations of Japanese American Women in Domestic Service (Philadelphia: Temple University Press, 1986); J. Yung, Unbound Feet: A Social History of Chinese Women in San Francisco (Berkeley: University of California Press, 1995).

${ }^{40}$ Hune, Creating Roise the Riveter, 6.

41 J. Wu, Doctor Mom Chung of the Fair-Haired Bastards: The Life of a Wartime Celebrity (Berkeley: University of California Press, 2005), 10. For more on women physicians, see R. Morantz-Sanchez, Conduct Unbecoming a Woman: Medicine on Trial in Turn-of-the-Century Brooklyn (New York: Oxford University Press, 1999); S. Wells, Out of the Dead House: Nineteenth-Century Women Physicians and the Writing of Medicine (Madison: University of Wisconsin Press, 2001). 
42 Wu, Doctor Mom Chung, 2-3.

43 Ibid., 1-2.

44 Ibid., 3.

45 Kerber, "Separate Spheres," 27.

${ }^{46}$ N. Cott and D. Gilpin Faust, "Recent Directions in Gender and Women's History," Organization of American Historians Magazine of History, 19/2 (March 2005): 4-5.

\section{Bibliography}

Allgor, C., Parlor Politics: In Which the Ladies of Washington Help Build a City and a Government (Charlottesville: University Press of Virginia, 2000).

Anderson, B., Joyous Greetings: The First International Women's Movement, 1830-1860 (New York: Oxford University Press, 2000).

Anderson, K., Wartime Women: Sex Roles, Family Relations, and the Status of Racial Ethnic Women in Modern America (Westport, CT: Greenwood Press, 1981).

Anderson, K., “Last Hired, First Fired: Black Women Workers during World War II,” Journal of American History, 69/1 (June 1982): 82-97.

Baker, P., "The Domestication of Politics: Women and American Political Society, 1780-1920," American Historical Review, 89 (June 1984): 620-47.

Bederman, G., Manliness and Civilization: A Cultural History of Gender and Race in the United States, 1880-1917 (Chicago: University of Chicago Press, 1995).

Blee, K., Women of the Klan: Racism and Gender in the 1920s (Berkeley: University of California Press, 1991).

Boris, E., "The Power of Motherhood: Black and White Activist Women Redefine the Political," in S. Koven and S. Michel (eds.), Mothers of a New World: Maternalist Politics and the Origins of Welfare States (New York: Routledge, 1993), 213-45.

Boris, E., Home to Work: Motherhood and the Politics of Industrial Homework in the United States (Cambridge: Cambridge University Press, 1994).

Boydston, J., Home and Work: Housework, Wages, and the Ideology of Labor in the Early Republic (New York: Oxford University Press, 1990).

Boylan, A., The Origins of Women's Activism: New York and Boston, 1797-1840 (Chapel Hill: University of North Carolina Press, 2002).

Brown, E., "Negotiating and Transforming the Public Sphere: African American Political Life in the Transition from Slavery to Freedom," Public Culture, 7 (Fall 1994): 108-24.

Brown, E., “To Catch a Vision of Freedom: Reconstructing Southern Black Women's Political History, 1865-1880," in V. Ruiz and Ellen C. DuBois (eds.), Unequal Sisters: A Multicultural Reader in U.S. Women's History, $3^{\text {rd }}$ edn. (New York: Routledge, 2000), 124-46.

Brown, K., Good Wives, Nasty Wenches, and Anxious Patriarchs: Gender, Race, and Power in Colonial Virginia (Chapel Hill: University of North Carolina Press, 1996).

Clark-Lewis, E., Living In, Living Out: African-American Domestics in Washington, D. C., 1910-1940 (Washington, D.C.: 1994).

Cobble, D., Dishing It Out: Waitresses and Their Unions in the Twentieth Century (Urbana: University of Illinois Press, 1991).

Cott, N., The Bonds of Womanhood: "Woman's Sphere” in New England, 1780-1835 (New Haven, CT: Yale University Press, 1977).

Cott, N., The Grounding of Modern Feminism (New Haven, CT: Yale University Press, 1987).

Cott, N., "Review of A Shared Experience: Men, Women, and the History of Gender," ed. L. McCall and D.Yacovone, American Historical Review, 105/1 (February 2000): 170-1.

Cott, N., and Faust, D., "Recent Directions in Gender and Women's History," Organization of American Historians Magazine of History, 19/2 (March 2005): 4-5.

Cott, N., Lerner, G., Sklar, K., DuBois, E., and Hewitt, N., "Considering the State of U.S. Women's History," Journal of Women's History, 15/1 (2003): 145-63.

Crawford, V., Rouse, J., and Woods, B. (eds.), Women in the Civil Rights Movement: Trailblazers and Torchbearers, 1941-1945 (Bloomington: Indiana University Press, 1993).

Cutter, B., Domestic Devils, Battlefield Angels: The Radicalism of American Womanhood, 1830-1870 (DeKalb: Northern Illinois University Press, 2003). 
Dalton, K., Theodore Roosevelt: A Strenuous Life (New York: Alfred A. Knopf, 2002).

Dayton, C., Women before the Bar: Gender, Law, and Society in Connecticut, 1639-1789 (Chapel Hill: University of North Carolina Press, 1995).

Deutsch, S., No Separate Refuge: Culture, Class, and Gender on the Anglo-Hispanic Frontier in the American Southwest, 1880-1940 (New York: Oxford University Press, 1987).

Dickson, L., "Lifting as We Climb: African American Women's Clubs of Denver, 1890-1925," in E. Jameson and S. Armitage (eds.), Writing the Range: Race, Class, and Culture in the Women's West (Norman: University of Oklahoma Press, 1997), 372-92.

Dorsey, B., Reforming Men and Women: Gender in the Antebellum City (Ithaca, NY: Cornell University Press, 2002).

Freeman, J., A Room at a Time: How Women Entered Party Politics (Lanham, MD: Rowman and Littlefield, 2000).

Freedman, E., "Separatism as Strategy: Female Institution Building and American Feminism, 1870-1930," in Feminism, Sexuality, and Politics: Essays by Estelle B. Freedman (Chapel Hill: University of North Carolina Press, 2006), 21-36. [Original publication: Freedman, E., "Separatism as Strategy: Female Institution Building and American Feminism, 1870-1930," Feminist Studies, 5/3 (Fall 1979): 512-29.]

Freedman, E., "Separatism Revisited: Women's Institutions, Social Reform, and the Career of Miriam Van Waters," in L. Kerber, A. Kessler-Harris, and K. Kish Sklar (eds.), U.S. History as Women's History: New Feminist Essays (Chapel Hill: University of North Carolina Press, 1995), 170-88.

Giddings, P., Where and When I Enter: The Impact of Black Women on Race and Sex in America (New York: Bantam Books, 1984).

Gilmore, G., Gender and Jim Crow: Women and the Politics of White Supremacy in North Carolina, 1896-1920 (Chapel Hill: University of North Carolina Press, 1996).

Ginzberg, L., Women and the Work of Benevolence: Morality, Politics, and Class in the Nineteenth-Century United States (New Haven, CT: Yale University Press, 1990).

Glenn, E., Issei, Nisei, War Bride: Three Generations of Japanese American Women in Domestic Service (Philadelphia: Temple University Press, 1986).

Gustafson, M., Women and the Republican Party, 1854-1924 (Urbana: University of Illinois Press, 2001).

Hewitt, N., "Beyond the Search for Sisterhood: American Women's History in the 1990s," in V. Ruiz and E. DuBois (eds.), Unequal Sisters: A Multicultural Reader in U.S. Women's History, $3^{\text {rd }}$ edn. (New York: Routledge, 2000), 1-19.

Hewitt, N., Southern Discomfort: Women's Activism in Tampa, Florida, 1880s-1920s (Urbana: University of Illinois Press, 2001).

Hewitt, N., "Taking the True Woman Hostage," Journal of Women's History, 14/1 (2002): 156-62.

Higginbotham, E., Righteous Discontent: The Women's Movement in the Black Baptist Church, 18801920 (Cambridge, MA: Harvard University Press, 1993).

Hine, D., Hine Site: Black Women and the Re-Construction of American History (New York: Carlson Publishing, 1994).

Hine, D., King, W., and Reed, L. (eds.), "We Specialize in the Wholly Impossible": A Reader in Black Women's History (New York: Carlson Publishing, 1995).

Honey, M. (ed.), Bitter Fruit: African American Women in World War II (Columbia: University of Missouri Press, 1999).

Honey, M. Creating Rosie the Riveter: Class, Gender, and Propaganda during World War II (Amherst: University of Massachusetts Press, 1984).

Hune, S., and Nomura, G. (eds.), Asian/Pacific Islander American Women: A Historical Anthology (New York: New York University Press, 2003).

Hunter, T., "Domination and Resistance: The Politics of Wage Household Labor in New South Atlanta," Labor History, 34 (Spring-Summer 1993): 205-20.

Hunter, T., To 'Joy My Freedom: Southern Black Women's Lives and Labors after the Civil War (Cambridge: Cambridge University Press, 1997).

Jameson, E., "Toward a Multicultural History of Women in the Western United States," Signs, 13/4 (Summer 1988): 761-91.

Jameson, E., and Armitage, S. (eds.), Writing the Range: Race, Class, and Culture in the Women's West (Norman: University of Oklahoma Press, 1997). 
Jones, J., Labor of Love, Labor of Sorrow: Black Women, Work, and the Family from Slavery to the Present (New York: Basic Books, 1985).

Jones, J., "Race and Gender in Modern America," Reviews in American History, 26/1 (1998): 220-38.

Kerber, L., "Separate Spheres, Female Worlds, Woman's Place: The Rhetoric of Women's History," The Journal of American History, 75/1 (June 1988): 9-39.

Lamphere, L., Zavella, P., Gonzales, F., with Evans, P., Sunbelt Working Mothers: Reconciling Family and Factory (Ithaca: Cornell University Press, 1993).

Landes, J., "Further Thoughts on the Public/Private Distinction," Journal of Women's History, 15/2 (2003): 28-39.

Lasch-Quinn, E., Black Neighbors: Race and the Limits of Reform in the American Settlement Movement, 1890-1945 (Chapel Hill: University of North Carolina Press, 1993).

Lemke-Santangelo, G., Abiding Courage: African American Migrant Women and the East Bay Community (Chapel Hill: University of North Carolina Press, 1996).

Lopata, H., "The Interweave of Public and Private: Women's Challenge to American Society," Journal of Marriage and the Family, 55/1 (February 1993): 176-90.

McCall, L., and Yacovone, D. (eds.), A Shared Experience: Men, Women, and the History of Gender (New York: New York University Press, 1998).

Moore, S., “ 'Not in Somebody's Kitchen': African American Women Workers in Richmond, California, and the Impact of World War II," in E. Jameson and S. Armitage (eds.), Writing the Range: Race, Class, and Culture in the Women's West (Norman: University of Oklahoma Press, 1997), 513-16.

Morantz-Sanchez, R., Conduct Unbecoming a Woman: Medicine on Trial in Turn-of-the-Century Brooklyn (New York: Oxford University Press, 1999).

Norton, M., Founding Mothers and Fathers: Gendered Power and the Forming of American Society (New York: Alfred A. Knopf, 1996).

Olsen, C., "Respecting 'the Wise Allotment of Our Sphere': White Women and Politics in Mississippi, 1840-1860," Journal of Women's History, 11/3 (Autumn 1999): 104-25.

Orleck, A., "Rose Schneiderman," in G. J. Barker-Benfield and C. Clinton (eds.), Portraits of American Women: From Settlement to the Present (New York: St. Martin's Press, 1991), 401-21.

Pascoe, P., Relations of Rescue: The Search for Female Moral Authority in the American West (New York: Oxford University Press, 1990).

Pleck, E., "Two Worlds in One," Journal of Social History, 10/2 (1976): 178-95.

Rauchway, E., "A Gentlemen's Club in a Woman's Sphere: How Dorothy Whitney Straight Created the New Republic," Journal of Women's History, 11/2 (1999): 60-85.

Robnett, B., How Long? How Long? African American Women in the Struggle for Civil Rights (New York: Oxford University Press, 1996).

Rose, M., “' Woman Power Will Stop Those Grapes': Chicana Organizers and Middle-Class Female Supporters in the Farm Workers' Grape Boycott in Philadelphia, 1969-1970," Journal of Women's History, (Winter 1995): 6-36.

Ruiz, V., Cannery Women, Cannery Lives: Mexican Women, Unionization, and the California Food Processing Industry, 1930-1950 (Albuquerque: University of New Mexico Press, 1987).

Ruiz, V., and DuBois, E. (eds.), Unequal Sisters: A Multicultural Reader in U.S. Women's History, $3^{\text {rd }}$ edn. (New York: Routledge, 2000).

Rupp, L., and Taylor, V., Survival in the Doldrums: The American Women's Rights Movement, 1945 to the 1960s (New York: Oxford University Press, 1987).

Ryan, M., Women in Public: From Banners to Ballots, 1825-1880 (Baltimore, MD: Johns Hopkins University Press, 1990).

Salem, D., To Better Our World: Black Women in Organized Reform, 1890-1920 (New York: Carlson Publishing, 1990).

Scott, A., "Most Invisible of All: Black Women's Voluntary Associations," Journal of Southern History, 56 (February 1990): 3-22.

Shaw, S., "Black Club Women and the Creation of the National Association of Colored Women," Journal of Women's History, 3 (Fall 1991): 10-25.

Sklar, K., "Two Political Cultures in the Progressive Era: The National Consumers' League and the American Association for Labor Legislation," in L. Kerber, A. Kessler-Harris, and K. Kish 
Sklar (eds.), U.S. History as Women's History: New Feminist Essays (Chapel Hill: University of North Carolina Press, 1995), 36-62.

Smith-Rosenberg, C., "The Female World of Love and Ritual: Relations between Women in Nineteenth-Century America," Signs, 1 (Autumn, 1975): 1-29.

Thurner, M., "Subject to Change: Issues and Paradigms of U.S. Feminist History," Journal of Women's History, 9/2 (Summer 1997): 122-46.

Ulrich, L., A Midwife's Tale: The Life of Martha Ballard, Based on Her Diary, 1785-1812 (New York: Vintage Books, 1991).

Varon, E., "Tippecanoe and the Ladies, Too: White Women and Party Politics in Antebellum Virginia," Journal of American History, 82 (September 1995): 494-521.

Watts, S., Rough Rider in the White House: Theodore Roosevelt and the Politics of Desire (Chicago: University of Chicago Press, 2003).

Wells, S., Out of the Dead House: Nineteenth-Century Women Physicians and the Writing of Medicine (Madison: University of Wisconsin Press, 2001).

Welter, B., “The Cult of True Womanhood, 1820-1860," American Quarterly, 18 (Summer 1966): 151-74.

White, D., Ar'n't I a Woman?: Female Slaves in the Plantation South (New York: Norton, 1985).

White, D., Too Heavy a Load: Black Women in Defense of Themselves, 1894-1994 (New York: W. W. Norton, 1999).

Wilson, S., "Melville and the Architecture of Antebellum Masculinity," American Literature, 76/1 (2004): 59-87.

Wu, J., Doctor Mom Chung of the Fair-Haired Bastards: The Life of a Wartime Celebrity (Berkeley: University of California Press, 2005).

Yee, S., Black Women Abolitionists: A Study in Activism, 1828-1860 (Knoxville: University of Tennessee Press, 1992).

Yung, J., Unbound Feet: A Social History of Chinese Women in San Francisco (Berkeley: University of California Press, 1995).

Zavella, P., Women's Work and Chicano Families: Cannery Workers of the Santa Clara Valley (Ithaca: Cornell University Press, 1987). 